\title{
Mixing the Useful and the Sweet, or: The Delights of Admonition An Essay in Comparative Literature
}

\author{
PETER RUSSELL
}

"Omne tulit punctum qui miscuit utile dulci, Lectorem delectando pariterque monendo."

(Horace, Ars Poetica)

Although literary relationships between England and Germany have been the subject of thorough discussion and analysis since they first became so significant towards the end of the eighteenth century, there is one German work of literature which escapes all mention in books on the subject. Yet not only is it a book described by Fritz Martini in his Deutsche Literaturgeschichte as 'unsterblich', but it is probably a more familiar book in England than perhaps any of the other German masterpieces which spring to mind: more widely read, and by successive generations too, than Faust, The Trial or The Magic Mountain; more widely read even, and certainly more enduring in its appeal, than less exalted though estimable bestsellers such as Feuchtwanger's Jew Süss or Remarque's All Quiet on the Western Front. It was first published in Germany in 1845; an instant success, it soon afterwards appeared in English and several other languages. Since then it has been continuously reprinted, in both German and English editions; it continues to be found in book-shops in both countries. The book is Struwwelpeter, its author Heinrich Hoffmann. ${ }^{1}$

Ah, a children's book, may be the reaction; but a classic nonetheless. Yet some older English editions of Struwwelpeter do not even indicate its authorship - no doubt a measure dictated by the wars with Germany, but unthinkable for any of the other masterpieces mentioned. Nor will the name of Heinrich Hoffmann, or indeed the title of his famous book, be found in the standard English encyclopaedias: both are missing from the current Encyclopaedia Britannica, from Chamber's Encyclopaedia, and from Everyman's. This is extraordinary, given the book's fame in popular culture, and the generations of British children who have made its acquaintance. But the Germans do not serve Hoffmann very well either. True, as indicated, Martini does call Struwwelpeter 'unsterblich', but even immortality, it would appear, secures one no more than a single line of print in his Deutsche Literaturgeschichte. Other German 
histories of literature do not mention the work at all, no doubt primarily because it is regarded as a book for infants; though its omission perhaps also reflects a proclivity in some German scholars to believe that something that is funny cannot be taken seriously, and conversely, that something that is serious cannot be permitted to be funny. To find out anything about Hoffmann today, indeed, unless one is willing to research the long out-of-print specialist literature on him, ${ }^{2}$ one must have recourse to German encyclopaedias (here the older editions inform most generously), and similar reference works. ${ }^{3}$

Three facts about Heinrich Hoffmann (or, as he called himself with the addition of his wife's maiden name, Hoffmann-Donner) are of especial interest to the reader of Struwwelpeter. The first is that he was a doctor by profession, who was born in Frankfurt am Main in 1809, and after training held various posts in his native city, notably that of medical director of the Frankfurt Lunatic Asylum from 1851 to 1888 . One result of his activities was a publication of 1859 entitled Beobachtungen und Erfahrungen über Seelenstörung und Epilepsie in der Irren-Anstalt zu Frankfurt am Main. Particularly interesting is the fact that Hoffmann wrote and illustrated rhyming verses for the entertainment of his mentally disturbed patients.

The second interesting fact about Hoffmann is that his Struwwelpeter, like so many children's classics (they include Alice in Wonderland, Peter Rabbit, the Just So Stories, The Wind in the Willows and Winnie the Pooh) was originally written privately for a particular child, without thought of publication. Composed, illustrated and coloured in secret, it was laid under the Christmas-tree in 1844 for Hoffmann's first-born son Karl, then aged three-and-a-half. It lacked even a title: it was his children who christened the work Struwwelpeter. Hoffmann had to be pushed to have the work printed: it came out in an edition of 1500 copies at Christmas 1845, under the quaint pseudonym of Reimerich Kinderlieb. It sold out immediately; reappeared with enormous success in 1847, and was subsequently translated into'several European languages, appearing in English in 1848. (The French translation bears the title Pierre l'ébouriffé). When Hoffmann died in 1894, the book had already reached its 150 th impression; the 1906 Meyer reports 248 impressions, the 1926 Meyer 539.

The third interesting fact about Hoffmann is that he was one of those rare writers who produced only one enduringly successful work. Hoffmann was quite a prolific writer, who had already, before Struwwelpeter, published serious literary works, which included poetry and a successful dramatic comedy, ${ }^{4}$ and who continued to do so after Struwwelpeter. The unexpected success of the latter also prompted him, quite naturally, to try to repeat the trick with other books for children; but although some of these, notably König Nußknacker und der arme Reinhold (1851) and Im Himmel und auf der Erde (1858), achieved popular success in his life-time, it is Struwwelpeter, and Struwwelpeter alone, which has carried Hoffmann's name into the twentieth century.

Why is this? What is it about the book which has caused it to fascinate 
generation after generation of children? For Hoffmann was not doing anything new: verses for the instruction and edification of the young were a feature of the age, in the Germany of the 'Biedermeier' as in early Victorian England, where warning stories of just this kind were in popular circulation in the middle class. 5 Nor was there anything new in seeking to instruct by amusing, or in castigating by the use of humorous exaggeration - certainly not since Molière spoke of the duty of comedy as being "de corriger les hommes en les divertissant", and identified his aim in Le Tartuffe as being "d'attaquer par des peintures ridicules les vices de mon siècle". 6 Nor, to the adult eye which has cast off the powerful impressions of childhood, is Hoffmann's book of high artistic quality: his verses are wooden, his illustrations amateur.

One of the answers to this puzzle is adumbrated in the assertion just made: the book which to the uninvolved adult eye seems no more than the work of a gifted dilettante, exerts a tremendous fascination on children, because Hoffmann had a sure instinct for what children are like. He was obviously an astute and sympathetic observer of children, their perceptions, their behaviour, their particular temptations, dislikes and phobias; an astute observer too of those little but fierce battles between parent and child which form part of a child's upbringing, then as now: battles over such things as allowing nails to be cut or hair to be combed (Struwwelpeter), playing with matches (Paulinchen), thumb-sucking (Konrad), refusing food (Suppen-Kaspar), being fidgety and restless at table (Zappel-Philipp), and not looking where one is going (Hanns Guck-in-die-Luft), to mention some of the more familiar.

It is often said that the best children's books have been written by adults who have never fully outgrown the child in themselves. Certainly Hoffmann's particular gift is, while presenting his tales as the admonitions of a parent, to view things repeatedly from the perspective of a child. This paradox of the book is already apparent on the title page, where a poem moralising sternly that only very good children will earn the right to read the book ("Wenn die Kinder artig sind/kommt zu ihnen das Christkind. . .") appears under the title, "Der Struwwelpeter, oder lustige Geschichten und drollige Bilder": an appeal which seems to have little to do with moral instruction. And 'lustig' and 'drollig' the stories are, in a way which is bound to appeal to children: the moral lessons are inseparable from the comic exaggerations which are so beloved of children, and which form the stuff of so many of today's cartoons and comics. Such figures as 'garstiger Struwwelpeter' himself, with his grotesque hair and finger-nails, or Suppen-Kaspar whom we view wasting in the space of four days from a tubby youth into a pitiful thread; the pile of ashes and pair of slippers which are all that is left of Paulinchen, the mountainous ruin which results from Zappel-Philipp's fidgeting at table: these are the kinds of exaggerations which delight the child as such. Thus too the animals which play such a constant role in the stories: the dog who revenges himself on 'der böse Friedrich' by eating his dinner, perched at the table with napkin round neck; the cats with 
handkerchiefs who weep over Paulinchen; the bespectacled hare who shoots the incompetent huntsman with his own flintlock; or the three fish who laugh at the dripping Hanns Guck-in-die-Luft after he is fished out of the river.

There is a deeper sense though in which Hoffmann views things from a child's perspective: he has an exceptional sense of what it is like to be a small child in a world of bigger people. This is revealed most strikingly in two of the tales: "Die Geschichte von den schwarzen Buben", where the gigantic dimensions of 'der große Nikolaus' and his inkwell reflect a child's-eye view of the adult world (notably of the punishing father-figure), and of course in "Die Geschichte vom Daumenlutscher", probably the most celebrated - or notorious - of all the stories. Freud was quick to point to the support the story offered for his theory of castration anxiety in the infant boy $;^{7}$ castration anxiety or not, one can see that the huge, powerful figure of the 'Schneider', with his monstrous scissors, once again embodies the terror of the punishing father-figure in a small child's imagination.

This brings us to an aspect of the Struwwelpeter stories often mentioned by adults: their cruelty. Many adults are repelled above all by the story just discussed: partly of course because few today regard thumb-sucking as a punishable offence, but mainly because the retribution pictured is so vindictively savage - down to the details of the blood dripping to the floor as the thumbs are snipped off, and the thumbless hands of the forlorn Konrad in the last picture. (A further detail perhaps not generally noticed is that the man's face forming a boss on the arch in the background, frowning with displeasure when Konrad disobeys his mother's orders, is seen beaming gleefully once the punishment has been executed!) Other aspects of Struwwelpeter which may attract the charge of undue cruelty are "Die Geschichte vom bösen Friedrich", with its depiction of sadistic brutality towards men and beasts, and the graphic illustration of the burning Paulinchen. It is perhaps not surprising that English parents with experience of the World Wars and knowledge of Nazi atrocities have been tempted to see in Struwwelpeter a sinister revelation of German national character.

There is no disputing the cruelty of some of these stories, just as there is no disputing the grimness of many of Grimms Märchen. But as parents know, what the adult experiences as grim often offers no such threat to the child's imagination; or rather, in the child's enjoyment fear is so compounded with delight that one cannot separate the two. Small children read, or listen to, the Struwwelpeter stories with a mixture of fascination and terror which constitutes their particular power. So much undoubtedly depends on the susceptibilities of the individual child that one dare not be dogmatic in this - but it can certainly be argued that in most cases such imaginative rehearsals are not only unlikely to damage the infant psyche, but are actually conducive to healthy growth! As a counterbalance to the charge of cruelty one might also draw attention to the enlightened attitude to racial prejudice expressed in "Die Geschichte von den schwarzen Buben". In addition, it must be pointed out that the cruelty in 
Struwwelpeter is not one-way: what may be viewed as the adult cruelty of "Die Geschichte vom Daumenlutscher" is balanced by the innate cruelty of the child Friedrich, who receives just retribution (from a dog, not an adult) for his lack of self-control. Indeed, one story, "Die Geschichte vom wilden Jäger", an oddity in that it alone of all the stories has no perceptible moral lesson for children, is perhaps there for no other reason than to show that grown-ups are not always on the winning side: for what could be a more drastic illustration of adult incompetence than this story of a man who is himself shot at by the hare he set out to pursue, and has to dive headlong into a well to save himself? Even his wife is not spared: the hare's shot splits her coffee cup in two. It is as if Hoffmann were telling his children: see, even Mama and Papa can be stupid, too.

In fact, the parents in Hoffmann's book are not strict, but indulgent, even neglectful: not only are they never seen actively punishing their children themselves - except insofar as one regards 'der große Nikolaus' and the 'Schneider' as disguised parent-figures - but they apparently do not insist that Struwwelpeter cuts his nails or combs his hair, do not scold Friedrich for breaking the furniture and killing the poultry, after warning Paulinchen leave her at home alone without supervision, do not resist Kaspar's tantrums but let him starve to death, and are merely angry when Philipp's fidgeting results in the destruction of their dinner (or do the besoms hanging decoratively from the last illustration hint at punishment to come?). The underlying message of the book is clearly that children's misdemeanours incur their own nemesis: in the workings of natural justice parents play only a minor role.

There is of course a danger in investigating these tales with too earnest or methodical an eye: Hoffmann was simply writing stories he hoped would delight his child, and children must remain the best judges of their success. Thus one must be cautious too about going into dark speculations about the German national character. Perhaps the suggestion will not be regarded as altogether foolish, however, that one character in the collection does provide a key to an archetypal trait in the German character: not 'der böse Friedrich', but the innocent Hanns Guck-in-die-Luft, the child who is so completely absorbed in his own thoughts that he walks into a river and has to be fished out again. What more fitting symbol could one seek for that habit of intellectual introspection, that speculative bent, that dreamy, other-worldly absorption in ideas and the ideal, which the world - up to 1945 , anyway - has so consistently identified with the countrymen of Kant, Schiller and Beethoven? "Ein eigentümlicher Fehler der Deutschen ist," wrote Hoffmann's contemporary Schopenhauer, "daß sie, was vor ihren Füßen liegt, in den Wolken suchen" ion has been accompanied by a sometimes disastrous failure to perceive and cope with the world of practical realities, is neatly epitomised in Hoffmann's story.

Lest this discussion should seem to be succumbing completely now to that other characteristic sometimes attributed to Germans - a portentous solemnity 
- let us clear the air by proceeding to the second term of this comparative study: that collection of warning tales for children which constitutes the equivalent English masterpiece in the genre.

Hilaire Belloc's Cautionary Tales for Children was first published in 1907; it has been reprinted ever since in the same format, and its present publishers, who took it over in 1918, report that it still sells well. ${ }^{9}$ Unlike Struwwelpeter, it was a collaborative enterprise: the illustrations were drawn by Basil Blackwood, identified only by his initials, "B.T.B.".

There are certainly similarities between Struwwelpeter and the Cautionary Tales for Children; but as will be shown, beneath the superficial likeness there are more fundamental differences. These can be attributed to several interlinked factors: the difference in the author's character and temperament, a difference in aims, the difference in generation, and, not least, the difference in nationality.

Hilaire Belloc was of course a very different person from Heinrich Hoffmann: a professional writer, propagandist and Catholic apologist of immense vitality and versatility, who during much of his lifetime (1870-1953) was one of the best-known public and literary figures in England. His output encompassed books of poetry, fiction, satire, literary criticism, biography, history, theology, economic and social theory, travel, and voluminous essays; with G.K. Chesterton, a figure with whom he was frequently associated, he enjoyed a large reading public in his time, and the Belloc oeuvre is of staggering proportions. The eclipse of his reputation since his death, indeed during his own later years, is remarkable: Belloc today elicits little public or critical attention, even for what is arguably his outstanding achievement, his poetry, and now appears very much as the conservative representative of a bygone era, the champion of a pre-industrial Europe which was rapidly fading in his own life-time. It would be a cruel irony if the man who wrote

When I am dead, I hope it may be said:

"His sins were scarlet, but his books were read"

were in fact to be remembered primarily as the author of the Cautionary Tales for Children.

For the Cautionary Tales were tossed off as a trifle amidst other more serious projects. Belloc was the Liberal M.P. for South Salford at the time, but in addition to his political duties contrived to do a great deal of writing. His biographer, Robert Speaight, gives us an idea of Belloc's intellectual industry at the time:

Between his election to Parliament in January 1906 and the dissolution of the same Parliament in December 1909 - virtually four years - Belloc published his longest biography, Marie Antoinette; four volumes of essays, most of which had already appeared in the Morning Post and elsewhere; two books of travel and topography; two satirical novels; one volume of verse; and four pamphlets. The output would have been remarkable for a 
man whose whole time was given to writing; for a busy M.P. and lecturer, of sociable habits and diverse interests, it was astonishing. 10

It was not the first time Belloc had tried his hand at such whimsy - the Cautionary Tales had been preceded by The Bad Child's Book of Beasts (1896), More Beasts for Worse Children (1897) and A Moral Alphabet (1899); it was to be followed by the less successful New Cautionary Tales (1930). ${ }^{11}$ But it certainly became his most popular work of the kind, and was, according to his biographer, "greatly helped by Clara Butt, who sang the Cautionary Tales to immense audiences up and down the country". 12 The nature of the music to which she sang them is not recorded.

Belloc, unlike Hoffmann, was a highly accomplished poet, and the reader of the Cautionary Tales is at once aware of the superiority of the verse qua verse: it is deft, fluent, and marked by an elegance and felicitous wit which remind us that Belloc's father, and his paternal ancestors, were French. But that Belloc knew Struwwelpeter, and that Struwwelpeter was in his mind when he wrote his work, is suggested by two main pieces of evidence. First, the Cautionary Tales are specifically directed at a different age-group: while Struwwelpeter is advertised "für Kinder von 3 bis 6 Jahren", the Cautionary Tales bear the legend: "Designed for the Admonition of Children between the ages of eight and fourteen years". Second, none of Belloc's eleven cautionary lessons duplicates any of Hoffmann's ten, something that can hardly be ascribed to coincidence. The parallels in content which do exist are really very slight. For example, both Paulinchen and Matilda survive only as a heap of smoking ashes; but for one this is the result of playing with fire, for the other the result of lying so constantly that no-one believes her when she is telling the truth:

For every time she shouted "Fire!"

They only answered "Little Liar!"

And therefore when her Aunt returned,

Matilda, and the House, were Burned.

The only other obvious thematic parallel lies in the fact that both books warn against playing with dangerous objects: but for Hoffmann it is matches, while for Belloc it is a loaded gun ("Algernon, Who played with a Loaded Gun, and, on missing his Sister was reprimanded by his Father"), and a gas-filled balloon ("George, Who played with a Dangerous Toy, and suffered a Catastrophe of considerable Dimensions").

As the last example suggests, Belloc uses the same basic device of comic exaggeration to put his message across: indeed, the punishments his children suffer are usually a great deal more drastic in proportion to the crime than are those devised by Hoffmann. Belloc's children suffer a variety of painful deaths, including being eaten by a lion ("Jim, Who ran away from his Nurse"), death in intestinal agonies ("Henry King, Who chewed bits of String"), incineration ("Matilda, Who told Lies"), and being flattened by a marble bust ("Rebecca, 
Who slammed Doors for Fun"). The non-lethal punishments range from the destruction by explosion of home, relatives and domestic staff ("George, Who played with a Dangerous Toy"), being sent out to govern New South Wales ("Lord Lundy, Who was too Freely moved to Tears, and thereby ruined his Political Career"), and becoming a boot-black ("Godolphin Horne, Who was cursed with the Sin of Pride"), to a severe beating ("Franklin Hyde, Who caroused in the Dirt") and mere parental reprimand "Algernon, Who played with a Loaded Gun", and "Hildebrand, Who was frightened by a Passing Motor"). Although, as in Struwwelpeter, the emphasis here is more on natural justice than parental punishment, the nature of these fates points to an essential difference between Hoffmann and Belloc, a difference in aims which rests also on a difference in generation and in country. Belloc is writing for Edwardians, not Victorians; and he is writing for the English Upper Class, a world of exceptional wealth and leisure. All the children in these stories are the children of the privileged: they have nurses ( $\mathrm{Jim}$ ), live in large homes (Matilda) with enormous domestic staffs (George), have connections with the Court (Godolphin Horne), ancestors of military distinction (Hildebrand) or belong to families with noble titles and major political influence, who despise the parvenu (Lord Lundy). Where the parent's profession is mentioned it is that of doctor (Algernon) and banker - clearly Jewish (Rebecca); places of residence named are Berkeley Square (Godolphin Horne), Palace Green, Bayswater (Rebecca) and Savile Row (George). Even the hotel where Godolphin Horne is reduced to blacking boots is the Savoy. The very names of the children, and the illustrations by Basil Blackwood, reinforce the impression. The emphasis on wealth is particularly blatant in the tale of Hildebrand, whose father proposes to cure him of his fear of automobiles by taking him to town to buy some! It reaches its climax in the last tale, that of Charles Augustus Fortescue, a tale which has no equivalent in Struwwelpeter, for it relates the positive reward which comes to the child who is always virtuous. There is absolutely no doubt as to what that reward is: money and status:

He rose at once in his Career, And long before his Fortieth Year

Had wedded Fifi, Only Child

Of Bunyan, First Lord Aberfylde.

He thus became immensely Rich, And built the Splendid Mansion which

Is called "The Cedars, Muswell Hill,"

Where he resides in Affluence still

To show what Everybody might

Become by SIMPLY DOING RIGHT.

It need hardly be said that this is a much less austere world, and a much less austere morality, than those of Heinrich Hoffmann, whose book, designed as a 
Christmas present, promised a rather more Christian reward. To compare the two prologues is indeed instructive; for while Hoffmann earnestly advises his readers that good children will be visited at Christmas by the gift-bearing Christchild, Belloc is at pains to point out that he is not to be taken seriously at all:
And is it True? It is not True.
And if it were it wouldn't do,
For people such as me and you
Who pretty nearly all day long
Are doing something rather wrong.
Because if things were really so,
You would have perished long ago,
And I would not have lived to write
The noble lines that meet your sight,
Nor B.T.B. survived to draw
The nicest things you ever saw.

This cynical introduction denies any real moral intent in the book; it points to its essentially ironic and tongue-in-cheek nature. One cannot overlook either the elements of sheer tomfoolery in the tales and their illustrations - as in the story of Hildebrand's Great-Grandfather, whose doughty example is invoked to cure Hildebrand of his fear of motor-cars: he is shown as losing his left leg to a cannon-ball no less than three times in three battles of 1815 , given in reverse chronological order, then as dying, with a wooden right leg, at the Battle of Trafalgar which took place ten years previously, his breast pierced by an arrow! The Cautionary Tales for Children are indeed a parody of the genre, intended as much for the entertainment of adults as for that of children, a parody which serves at the same time as a persiflage of the English Upper Class.

For there is no doubt that the Cautionary Tales, among other things, are a splendid caricature of the English Upper Class, at what may be seen historically as its apogee: privileged, comfortable, authoritarian, self-assured, secure in the protection of Monarchy and basking in the rays of an Imperial sun which seemed destined never to set. It is a class riddled with self-congratulatory snobbery, Belloc implies, in which feelings are sacrificed to 'good form', for which respectability is next to godliness, and solvency is identified with virtue. That it is so astutely caricatured, and that Belloc has so little respect either for respectability or for the precepts professed by the respectable, reminds us that the once solid-seeming values of the nineteenth century were being increasingly called into question in that generation, in England as in Germany, and that Belloc was, after all, a contemporary almost to the year of Heinrich Mann. Belloc did in fact, in his more serious writings, react fiercely against the complacency of the British wealthy, and their patronising indifference to social and economic abuses of the time such as poverty and inequality; it was a stance he shared with his contemporaries, Shaw, Chesterton and Wells. His belief that the English 
people were becoming more and more subservient to a dominant plutocracy is a major theme of his social and political writings, expressed for example in his book The Servile State, of 1912.13

At the same time, we must beware of over-emphasizing this aspect of the Cautionary Tales. In mocking the Upper Class, Belloc has also set up an enduring monument to it, whose features betray as much attachment as detachment. Belloc's stance of affectionate deprecation, of amused irony, could be described as quintessentially English: it points to that distinctive ability of the English to ridicule themselves, and yet accept themselves, which has made popular satire in our century so different a thing in England from its equivalent in Germany. A perusal of the 1907 issues of Punch and Simplicissimus illustrates the point: in one country amused self-critique, in the other contemptuous and savage attack from outside; in one country a relatively tolerant relationship between government and governed, in the other fiercely divisive antagonisms. George Orwell, writing of Dickens, went so far as to complain that the British public was impervious to real satirical attack. The effect, he said, was comparable to the result of beating an elephant violently: the elephant perceives the attack as a tickling sensation, and smiles vaguely. ${ }^{14}$

This is an atmosphere especially congenial to the deft mischief in which Belloc indulges in his Cautionary Tales. But the very fact that it is so indubitably mischief raises the question whether these tales can be said to have a real cautionary intent at all. Is a mischief-maker, after all, the most suitable person to dissuade others from mischief? Does he want to dissuade them? Is there not a sense in which Belloc - as his Introduction might be seen to imply - is colluding with children against adults, rather than admonishing them on behalf of adults?

Certainly, Belloc is not wholly on one side or the other - but then neither is Hoffmann, as we saw: both could be said, in different ways, to have a secret sympathy with the child's point of view. Here it is worth pointing out too that Belloc, however light-hearted his intentions may have been, was at least as perceptive and accurate as Hoffmann in his choice of typical children's behaviour with the distinction that Belloc is dealing with an older age-group than Hoffmann. Today's parents will recognize familiar kinds of behaviour in both books. This was confirmed by a private survey I conducted among friends with small children, listing all the 'vices' found in both books, in an arbitrary sequence, and asking them to indicate those which in their experience were most frequent. The results favoured Struwwelpeter, but not by a very wide margin: 'thumbsucking', 'objecting to having nails cut or hair combed' and 'refusing food' led the field there, while the most frequently observed Belloc vices were 'playing in the dirt', 'telling lies', 'bursting into tears at slight provocation' and 'slamming doors'!

The wording of the survey impressed on parents that information was not being sought on their attitudes, punitive or otherwise, to such behaviour, and 
that raises another and final question. Fashions in the upbringing of children have changed so much since the days of Hoffmann or Belloc, there is so much more emphasis today on liberality and flexibility in the parent, and on the virtues of 'self-expression' in the child, that it might seem that the cautionary tale is an obsolete genre. It might seem, in other words, that Hoffmann and Belloc both reflect a belief in strict precept which no longer generally prevails in us, the enlightened heirs of Freud and Piaget; or else that they reflect certainties of which we, a shaken and doubting generation, are no longer in possession.

While there may be some truth in this, it does not explain the continuing popularity of Struwwelpeter and the Cautionary Tales for Children: that they are still selling suggests that their authors tapped a spring which runs deeper than changes in fashion. Perhaps the truth is that, while parental beliefs and attitudes change, children's impulses do not, and it is about children's impulses that the books were written, with both an accuracy and a good humour which renders them palatable to this day. Both writers recognize squarely that children are to be not merely endured, but enjoyed; both nimbly tread a tightrope between earnest moralising and light-hearted comedy, Hoffmann leaning further to the former side, Belloc to the latter. Much of the charm of both works rests in this ambivalence of intention, this mixing of the 'useful' and the 'sweet': for while neither work can be taken wholly seriously, and few would venture a claim as to the actual efficacy of these cautionary tales, it cannot be claimed either that their charm lies solely in their capacity to arouse laughter.

Indeed, as long as children, and children's literature exist, it is hard to imagine cautionary tales and verses of one kind or another disappearing altogether. In his memories of childhood Christmas presents, Dylan Thomas mentions both Struwwelpeter by name, and "books in which small boys, though warned, with quotations, not to, would skate on Farmer Garge's pond, and did, and drowned".15 I am sure many readers will have read similar books as children. Above all, whatever may be the health of the genre or its prospects for longevity, it has already produced at least two sturdy and perennially entertaining offspring: offspring indeed which, in their purveying of "useful Mirth, and salutary Woe"16, could be said to have attained the mature status of classics.

\section{Notes}

1 Frankfurter Originalausgabe, Loewes Verlag Ferdinand Carl, o.J. Reference to this and the other primary text discussed is so easy a matter that in the following discussion I have dispensed with specific page-references.

2 Relevant works are: (1) Das Struwwelpeter-Manuskript. Originalgetreue Nachbildung der Urhandschrift mit einem Bericht von Dr Heinrich Hoffmann und dessen Bildnis, nebst einem Begleitwort von G.A.E. Bogeng, Frankfurt a.M. 1925; (2) 'Struwwelpeter-Hoffmann' erzählt aus seinem 
Leben: Lebenserinnerungen Dr. Heinrich Hoffmanns, hrsg. von Eduard Hessenberg, Frankfurt a.M. 1926; (3) Gustav A.E. Bogeng, Der Struwwelpeter und sein Vater: Geschichte eines Bilderbuchs, Potsdam 1939. Cf. also Helmut Müller, "Der Struwwelpeter - Der langanhaltende Erfolg und das wandlungsreiche Leben eines deutschen Bilderbuchs", in Klaus Doderer (Hrsg.), Klassische Kinder- und Jugendliteratur, Kritische Betrachtungen, Weinheim 1969, 2. Aufl. 1970.

3 E.g. Meyers großes Konversationslexikon, 6. Aufl., Leipzig \& Wien 1906; Neue deutsche Biographie, Bd. 9, Berlin 1972.

4 Gedichte, Frankfurt a.M. 1842; Die Mondzügler. Eine Komödie der Gegenwart, Frankfurt a.M. 1843.

5 Cf. the works of Ann (1782-1866) and Jane Taylor (1783-1824).

6 "Le devoir de la comédie étant de corriger les hommes en les divertissant, j'ai cru que, dans l'emploi où je me trouve, je n'avois rien de mieux à faire que d'attaquer par des peintures ridicules les vices de mon siècle..." Premier Placet au Roi, prefacing Le Tartuffe, 1664.

7 Sigmund Freud, Introductory Lectures on Psycho-Analysis, in The Complete Psychological Works of Sigmund Freud, ed. James Strachey, London 1963, XVI, p. 369.

8 Arthur Schopenhauer, Parerga und Paralipomena, in Sämtliche Werke, hrsg. von Arthur Hübscher, Wiesbaden 1966, VI, p. 256.

9. Duckworth, London, in a reply to the author of July 1979.

10 Robert Speaight, The Life of Hilaire Belloc, London 1957, p. 241.

11 All of these are still in print (Duckworth), the first three still in their single editions.

12 Op. cit., p. 210.

13 Cf. the recent study by John P. McCarthy, Hilaire Belloc: Edwardian Radical, Indianapolis 1978.

14 George Orwell, "Charles Dickens”. In Critical Essays, London 1946, p. 8.

15 Dylan Thomas, Quite Early One Morning, London 1954, pp. 21-22; and A Prospect of the Sea, London 1955, p. 99.

16 Samuel Johnson, Prologue spoken by Mr Garrick at the Opening of the Theatre in Drury-Lane, 1747, in Johnson, The Complete English Poems, Penguin Books 1971, p. 82. 